\title{
Rancang Bangun Aplikasi Mobile Panduan Wisata Kota Palopo Menggunakan Augmented Reality Berbasis Location Service
}

\author{
${ }^{1}$ Khaidir Mubarak Putra Syam, ${ }^{2}$ Diah Asdiany* \\ ${ }^{1,2}$ Institut Agama Islam Negeri Palopo
}

\author{
Alamat Surat \\ Email: ${ }^{1,2}$ asdianydiah@gmail.com
}

Article History:

Received: 10-Nopember-2020; Received in Revised: 25-Nopember-2020; Accepted: 30-Nopember-2020

\begin{abstract}
ABSTRAK
Aplikasi ini menggunakan teknologi Augmented Reality (AR), Global Positioning System (GPS), dan sensor, serta memanfaatkan Google Maps API untuk menampilkan peta. Data tempat dan object lain di dapat dari database aplikasi. Data petunjuk arah jalan di dapat dari Google maps dengan menggunakan Google Maps Parameter. Dalam aplikasi ini terdapat beberapa fitur yang dapat membantu user seperti fitur get position, dan get direction.
\end{abstract}

Kata kunci: android, augmented reality, direction, google maps

\section{ABSTRACT}

This application label uses Augmented Reality technology (AR), the Global Positioning System ( GPS ), sensors, and utilizing Google Maps API to display the clarity article. Data objects lying on the place and can of database applications. Map data can guide direction roads in new articles from google to use Google Maps Parameters. In this application, there are some features Label That can help users Demolition get position features, and get directions.

\section{Keywords: android, augmented reality, direction, google maps}

\section{PENDAHULUAN}

Dewasa ini perkembangan teknologi perangkat smartphone cukup pesat. Sebelumnya, Smartphone hanya difungsikan sebagai alat komunikasi suara dan alat pengiriman pesan saja. Dengan semakin bertambahnya kebutuhan akan fitur-fitur baru untuk smartphone, membuat para vendor mengembangkan teknologi-teknologi baru untuk setiap produk mereka. Salah satu teknologi yang diaplikasikan di perangkat smartphone saat ini yaitu teknologi Global Positioning System (GPS). Dengan memanfaatkan GPS, pengguna dapat mengetahui posisi keberadaannya secara real time.

Location-Based Services atau sering disingkat dengan LBS merupakan sebuah layanan pada sebuah telepon genggam atau mobile device lain yang memanfaatkan teknologi GPS dalam pengaplikasiannya dan bergantung pada lokasi dari device. Dengan menggunakan location-based service, perangkat akan menentukan lokasinya, dan informasi ini digunakan untuk mendapatkan informasi berguna lainnya untuk user.

Di Indonesia location-based service sudah banyak digunakan untuk keperluan monitoring, lalu lintas, pariwisata hingga dunia bisnis. Sebagai contoh, TransJakarta menggunakan LBS untuk mengetahui keberadaan bus dan estimasi waktu kedatangan bis di suatu halte. Dalam dunia pariwisata, LBS sering digunakan bagi pemilik hotel, agensi perjalanan, toko, café, dan tempat wisata untuk memberikan informasi lokasi, sampai promo disekitar wisatawan. 
Kesulitan akan mendapatkan informasi lokasi wisata terdekat membuat banyak wisatawan kebingungan dalam mendapatkan informasi dan pemandu wisata yang murah, tahu banyak tentang lokasi wisata di suatu daerah, dan terpercaya tentunya, mengingat wisatawan rentan akan penipuan yang membuat tarif wisata menjadi lebih mahal dari biasanya. Wisatawan membutuhkan suatu media yang memberikan informasi lokasi wisata terdekat yang interaktif, cepat, dan tepat. Travel Map atau brosur perjalanan yang biasa digunakan oleh wisatawan untuk mengetahui informasi pariwisata disuatu daerah dapat membantu para wisatawan lokal dan mancanegara untuk mencari lokasi wisata, hotel, restaurant, café, atm, tempat hiburan, taman bermain, mall, dll. Travel Map biasa ditemukan dalam bentuk kertas brosur hanya menampilkan informasi pariwisata di daerah tertentu saja namun wisatawan tidak dapat mengetahui jarak antara lokasi wisata dengan lokasi tempat wisatawan berada.

Travel Map yang digabungkan dengan teknologi Augmented Reality dan Location-Based Services memungkinkan pencarian tempat wisata lebih cepat, mudah, dan interaktif. Karena tidak hanya menampilkan nama tempat dan alamat saja, tetapi juga menunjukan arah menuju lokasi yang hendak dituju. Sehingga wisatawan dapat mengetahui kearah mana harus pergi. Berdasarkan latar belakang yang telah dipaparkan inilah, penulis mencoba mengembangkan aplikasi travel booklet dengan user experience aplikasi yang mudah digunakan oleh pengguna. Dari penelitian ini penulis mengangkat judul "Rancang Bangun Aplikasi Mobile Panduan Wisata Palopo Menggunakan Augmented Reality Berbasis Location Service"

\subsection{Kajian Pustaka}

\section{Augmented Reality}

Augmented reality merupakan variasi dari Virtual Environments (VE), atau saat ini lebih sering disebut Virtual Reality. Pada teknologi VE, user benar-benar dibenamkan dalam lingkungan sintetis (buatan). Sebaliknya pada augmented reality, user dapat melihat dunia nyata dengan objek virtual yang ditambahkan pada benda atau objek nyata. Untuk lebih spesifiknya, augmented reality memiliki tiga karakteristik, sebagai berikut:

1. Menggabungkan objek nyata dan virtual

2. Bersifat interaktif secara real time

3. Merupakan animasi 3D

Menurut Milgram, augmented reality merupakan salah satu bagian dari Mixed Reality, sebagaimana yang didefinisikannya dalam Reality-Virtuality Continuum.

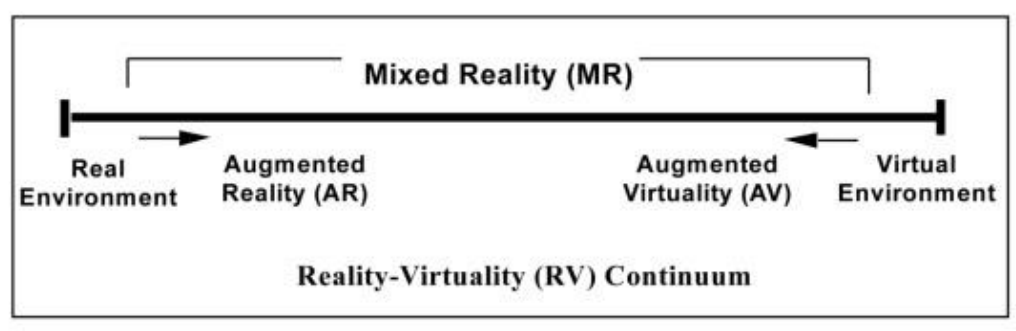

Gambar 1 Reality-Virtuality Continuum

\section{Jenis AR}

Augmented Reality (AR) terbagi dua macam berdasarkan metode penggunaannya yaitu Marker Augmented Reality dan Markerless Augmented Reality.

- Marker Augmented Reality merupakan sebuah metode yang memanfaatkan marker berupa ilustrasi hitam dan putih berbentuk persegi atau lainnya dengan batas hitam tebal dan latar belakang putih. Melalui posisi yang dihadapkan pada sebuah kamera komputer, maka komputer akan melakukan proses menciptakan dunia virtual 2D atau 3D. 


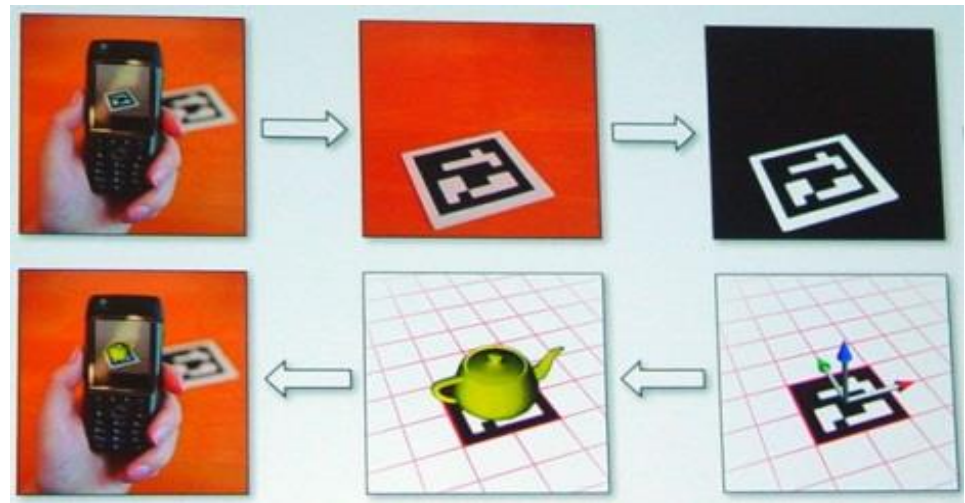

Gambar 2 Augmented Reality dengan Marker

- Markerless Augmented Reality yaitu metode AR yang tidak lagi memerlukan marker untuk menampilkan elemen dunia maya (virtual) saat menggabungkan dengan lingkungan dunia nyata. Penggunaan metode markerless biasa dimanfaatkan untuk face tracking, 3D object tracking dan motion tracking. Pada sistem ini diterapkan metode markerless augmented reality dengan memanfaatkan deteksi wajah sebagai trigger untuk menampilkan informasi pemilik wajah.

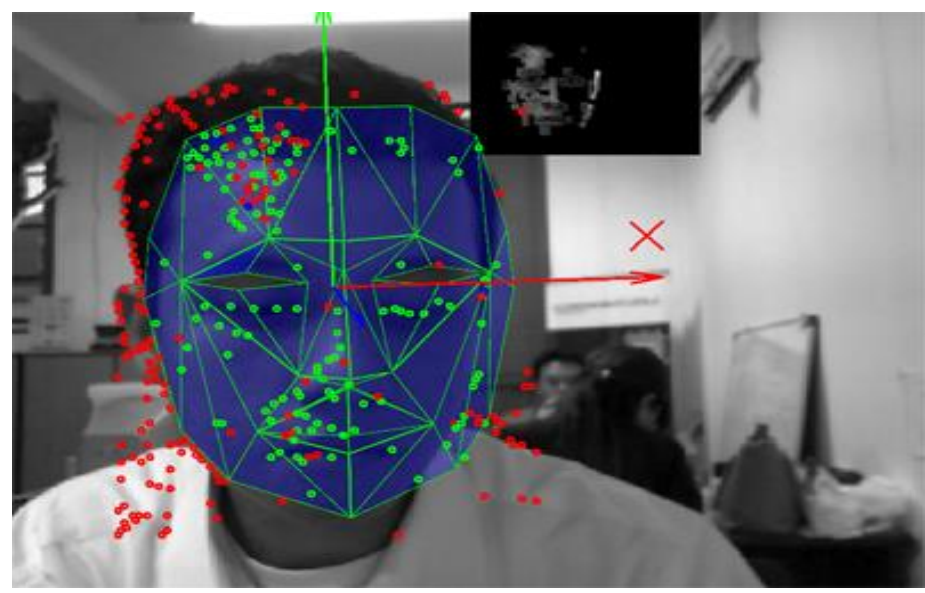

\section{Arsitektur Android}

Gambar 3 Markerless AR pada face tracking

Android merupakan software stack untuk perangkat mobile yang meliputi sistem operasi, middleware, dan aplikasi. Android dikembangkan oleh Open Handset Alliance, yang merupakan bawahan dari Google. Pengembangan Android ditujukan pada pasaran perangkat mobile, dengan alasan agar dapat mengakses internet dengan telepon seluler dan dapat menggunakannya sebagaimana fungsi komputer biasa.

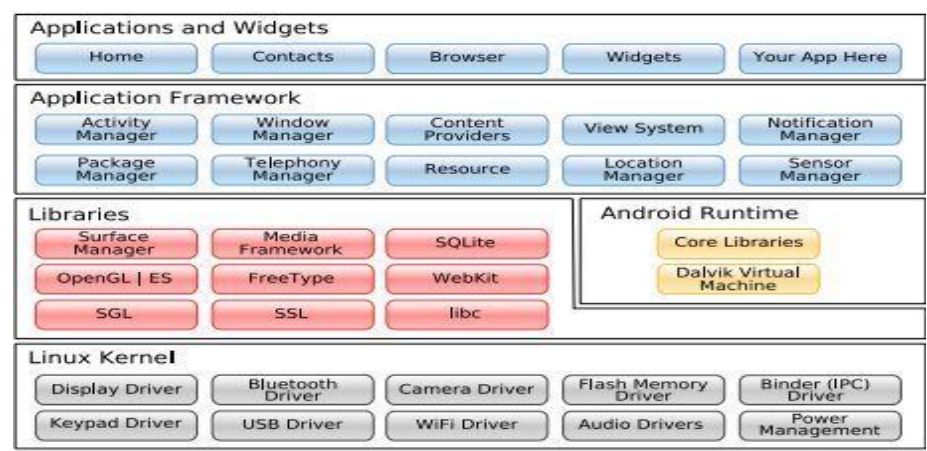

Gambar 4 Arsitektur Android 


\section{Location-based service}

Location based service atau layanan berbasis lokasi adalah istilah umum yang digunakan untuk menggambarkan teknologi yang digunakan untuk menemukan lokasi perangkat yang kita gunakan. Dua unsur utama LBS adalah:

a. Location Manager (API Maps)

Menyediakan tools/resource untuk LBS, Application Programming Interface (API) Maps menyediakan fasilitas untuk menampilkan, memanipulasi maps/peta beserta feature-feature lainnya seperti tampilan satelit, street (jalan), maupun gabungannya. Paket ini berada pada com.google.android.maps.

b. Location Providers (API Location)

Menyediakan teknologi pencarian lokasi yang digunakan oleh device/perangkat. API Location berhubungan dengan data GPS dan data lokasi real-time. API Location berada pada paket Android yaitu dalam paket android.location. Dengan Location Manager, kita dapat menentukan lokasi kita saat ini, Track gerakan/perpindahan, serta kedekatan dengan lokasi tertentu dengan mendeteksi perpindahan.

\section{Google Maps API}

GoogleMaps API adalah suatu library yang berbentuk JavaScript. Dengan menggunakan GoogleMaps API, kita dapat menghemat waktu dan biaya untuk membangun aplikasi peta digital yang handal, sehingga kita dapat fokus hanya pada data-data yang akan ditampilkan. Dengan kata lain, kita hanya membuat suatu data sedangkan peta yang akan ditampilkan adalah milik Google sehingga kita tidak dipusingkan dengan membuat peta suatu lokasi, bahkan dunia. Pada GoogleMaps API terdapat 4 jenis pilihan model peta yang disediakan oleh Google, diantaranya adalah:

a. ROADMAP, untuk menampilkan peta biasa 2 dimensi

b. SATELLITE, untuk menampilkan foto satelit

c. TERRAIN, untuk menunjukkan relief fisik permukaan bumi dan menunjukkan seberapa tingginya suatu lokasi, contohnya akan menunjukkan gunung dan sungai

d. HYBRID, akan menunjukkan foto satelit yang diatasnya tergambar pula apa yang tampil pada ROADMAP (jalan dan nama kota).

\section{Intel XDK}

Intel XDK adalah perangkat bagi para pengembang untuk mengembangkan aplikasi HTML5 hybrid untuk berbagai perangkat mobile dan aplikasi HTML5 lainnya seperti ekstensi Google Chrome, aplikasi Facebook, atau sebuah website mobile. Intel XDK dapat diinstall di sistem operasi Windows, OS X, dan Linux.Pada Intel XDK terdapat perangkat untuk melakukan coding, debugging, testing, dan build aplikasi yang telah kita kembangkan menjadi aplikasi web dan aplikasi HTML5 hybrid untuk berbagai platform mobile diantaranya iOS, Android, Windows 8 Store, Windows 8 Phone, dan lain-lain.

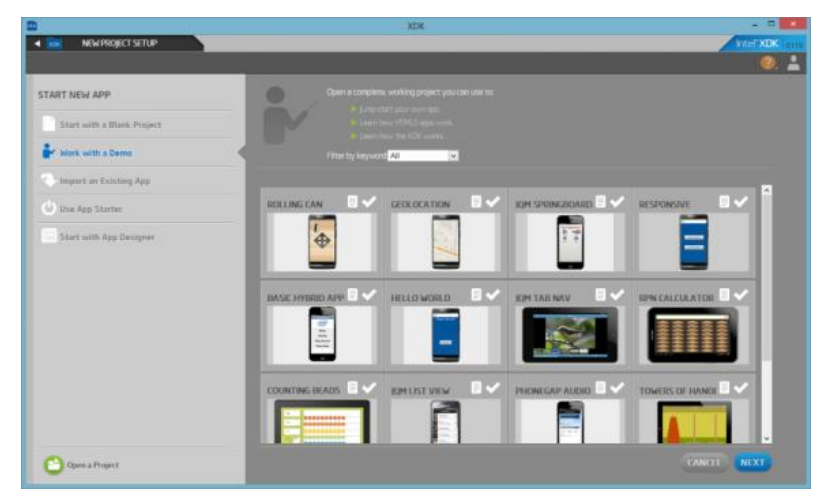

Gambar 5 Contoh tampilan antarmuka aplikasi intel XDK 


\section{METODE}

Secara umum, metodologi penelitian tersusun dalam diagram alir penelitian di bawah ini :

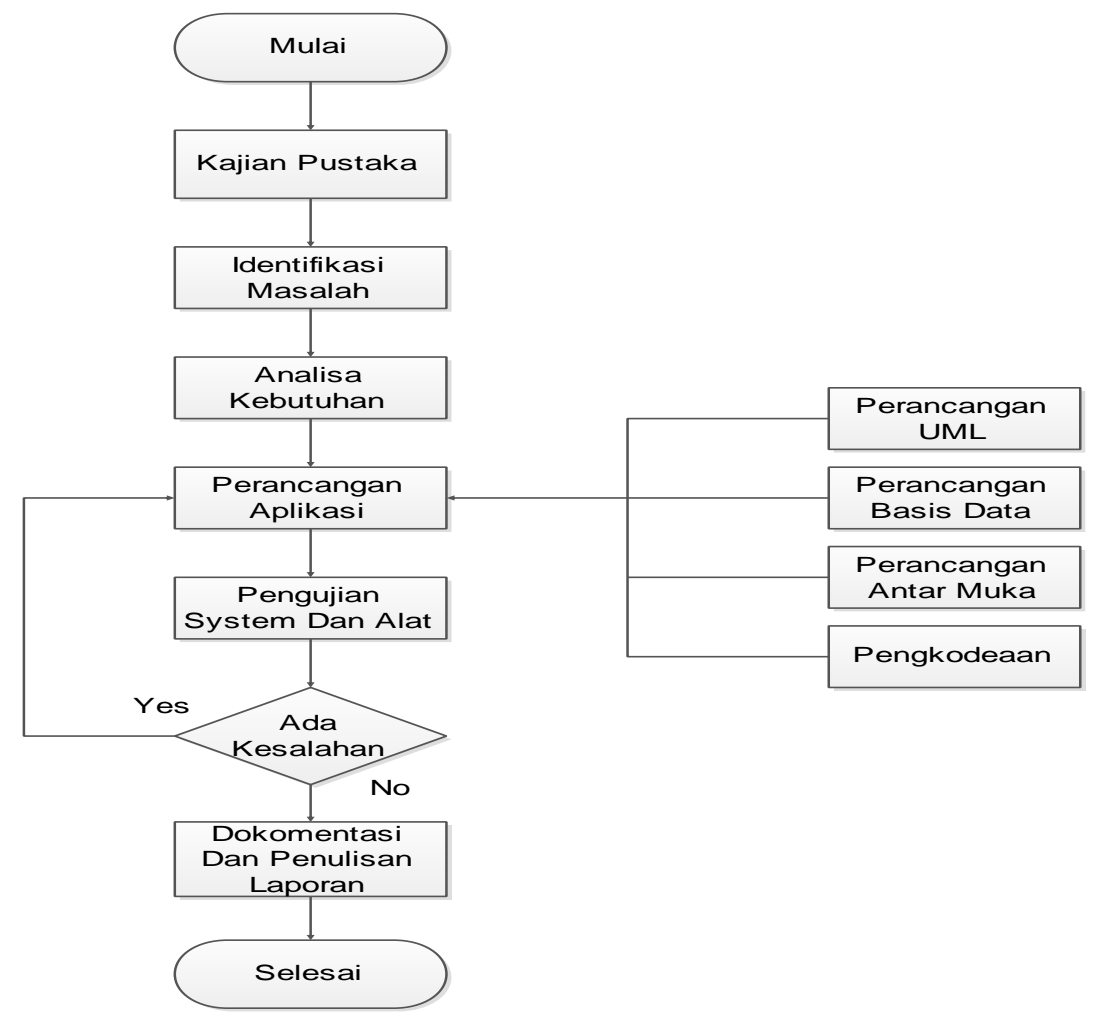

Gambar 6. Metodologi Penelitian

Metode Pengembangan Sistem yang digunakan dalam perancangan Sistem Informasi ini menggunakan Model Waterfall. Berikut adalah langkah-langkah Model Waterfall :

3.1 Requirement Analysis

Tahapan requirement analysis merupakan tahapan yang mendefinisikan sistem dan fitur-fitur yang dibutuhkan. Dilihat dari segi user, hanya terdapat satu role user dalam sistem. Gambar 3.1 merupakan use case diagram sistem, use case diagram tersebut menjelaskan apa saja yang dapat dilakukan oleh user ketika menggunakan aplikasi ini.

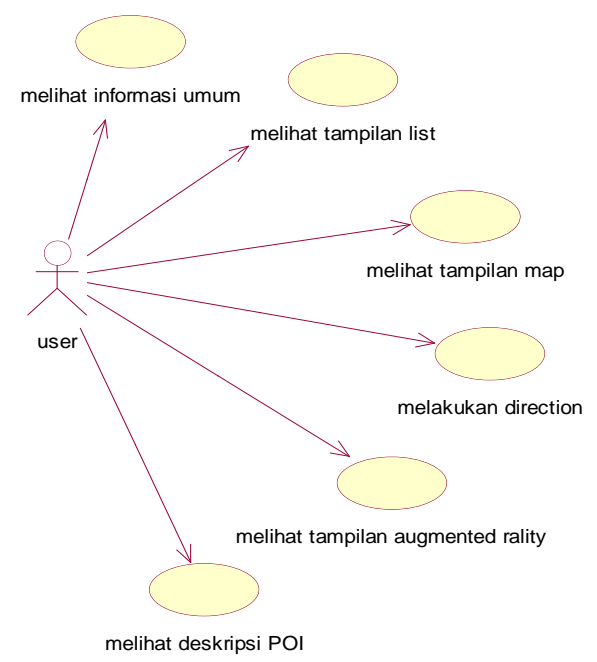

Gambar 7. Use Case Diagram pada user 
Gambar 3.2 merupakan use case diagram sistem pada administrator, use case diagram tersebut menjelaskan apa saja yang dapat dilakukan oleh administrator dalam mengembangkan aplikasi ini.

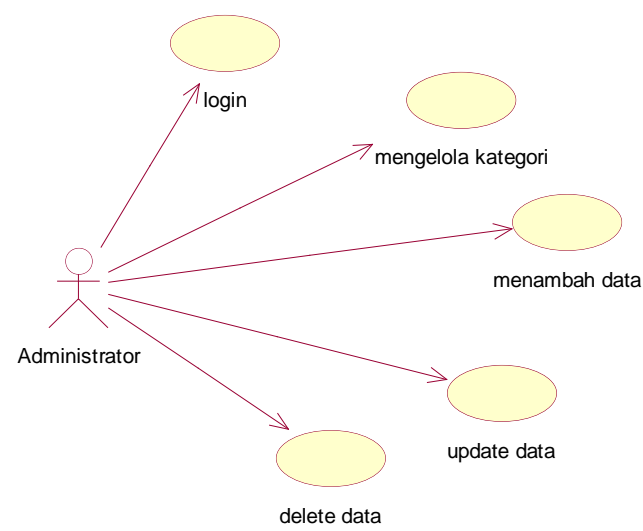

Gambar 8. Use Case Diagram pada administrator

Data Point of Interest merupakan data lokasi wisata dan tempat-tempat penting di daerah kota Palopo yang telah didefinisikan pada aplikasi ini oleh seorang administrator pada web admin, adapun lebih lengkapnya mengenai data-data tersebut dapat dilihat pada tabel 3.2. Data POI dibagi berdasarkan kategori lokasi nya. Nama yang tertera akan tampak ketika data-data POI ini berhasil ditampilkan menjadi objek dalam tampilan augmented reality.

Tabel 1. Tabel Data Point of Interest

\begin{tabular}{|c|c|c|c|c|c|}
\hline Id_lokasi & Nama_lokasi & Alamat_lokasi & Latitude & Longitude & Kategori \\
\hline Lok001 & $\begin{array}{c}\text { Ayam } \\
\text { penyet Ria }\end{array}$ & Jl. DR. Ratulangi & -2.9913987 & 120.1904175 & 1 \\
\hline Lok002 & $\begin{array}{l}\text { Restoran } \\
\text { Miramar }\end{array}$ & Jl. Andi Tadda baru & -2.9959074 & 120.1959364 & 1 \\
\hline Lok003 & $\begin{array}{c}\text { Sido } \\
\text { Mampir }\end{array}$ & Jl. Andi Djemma & -2.9928882 & 120.1952906 & 1 \\
\hline Lok004 & $\begin{array}{c}\text { Pantai } \\
\text { Labombo }\end{array}$ & Jl. Mungkasa & -3.0014774 & 120.2152297 & 2 \\
\hline Lok005 & $\begin{array}{l}\text { Istana Datu } \\
\text { Luwu }\end{array}$ & Jl. Andi Machulau & -2.9942404 & 120.1946031 & 2 \\
\hline Lok006 & $\begin{array}{c}\text { Bukit } \\
\text { Sampoddo }\end{array}$ & $\begin{array}{l}\text { Jl. Poros-Makassar } \\
\text { (Kec.Wara Selatan) }\end{array}$ & -3.048539 & 120.225983 & 2 \\
\hline Lok007 & $\begin{array}{c}\text { Rumah Adat } \\
\text { Langkanae }\end{array}$ & $\begin{array}{c}\text { Jl. Yusuf Arief (Kec. } \\
\text { Wara) }\end{array}$ & -2.9936253 & 120.1938819 & 2 \\
\hline Lok008 & $\begin{array}{c}\text { Hotel } \\
\text { Platinum }\end{array}$ & Jl. Andi Machulau & -2.9971243 & 120.1972003 & 3 \\
\hline Lok009 & Hotel Agro & Jl. Pongsimpin & -3.0171838 & 120.1820834 & 3 \\
\hline Lok010 & $\begin{array}{l}\text { Hotel Citra } \\
\text { Buana }\end{array}$ & Jl. Andi Djemma & -3.0120643 & 120.2052651 & 3 \\
\hline
\end{tabular}


Jurnal Ilmu Komputer dan Bisnis (JIKB), Special Issue Desember-2020, Vol.XI, No.2a, hal. 45-62

\begin{tabular}{|c|c|c|c|c|c|}
\hline Lok011 & BCA & Jl. Mangga & -3.0020036 & 120.1949797 & 4 \\
\hline Lok012 & Kantor Pos & Jl. Ahmad Yani no. 15 & -2.9948337 & 120.1951008 & 4 \\
\hline Lok013 & $\begin{array}{c}\text { City Market } \\
\text { Palopo }\end{array}$ & Jl. Dr. Ratulangi & -2.9906434 & 120.1869735 & 4 \\
\hline Lok014 & $\begin{array}{c}\text { Rumah Sakit } \\
\text { At-Medika }\end{array}$ & Jl. Jendral Sudirman & -3.0033874 & 120.1981753 & 4 \\
\hline Lok015 & $\begin{array}{c}\text { Pusat Niaga } \\
\text { Palopo }\end{array}$ & Jl. Mangga & -3.0007822 & 120.1955161 & 4 \\
\hline Lok016 & $\begin{array}{c}\text { Hotel } \\
\text { Awana }\end{array}$ & Jl. Latamacelling & -2.9938673 & 120.1961401 & 3 \\
\hline
\end{tabular}

Sistem yang dibuat juga bergantung pada hardware dan sistem operasi yang digunakan oleh perangkat smartphone Android yang akna digunakan. Unttuk dapat berjalan dengan baik, perangkat Android yang digunakan harus memenuhi persyaratan sebagai berikut.

1. Minimal menggunakan Andoid OS versi 2.3 (Gingerbread).

2. Memiliki kamera belakang

3. Memiliki GPS

4. Memiliki Akses internet

\subsection{System Design}

Pada dasarnya cara kerja sistem aplikasi adalah menampilkan informasi secara real time pada hasil tangkapan kamera. Adapun informasi-informasi yang muncul tersebut diambil dari Point of Interest (POI) yang berada di sekitar user. Perangkat smartphone biasanya sudah dilengkapi oleh kamera dan GPS. GPS berguna mengetahui lokasi di mana user berada saat itu. Sehingga saat aplikasi dijalankan user hanya perlu mengarahkan perangkat smartphone mereka ke suatu arah, kemudian pada layar akan tampak tampilan kamera yang ditambahkan informasi mengenai lokasi wisata di mana kamera pada smartphone tersebut diarahkan. Pada perancangan sistem, aplikasi yang dibuat menggunakan Intel XDK akan diujicobakan di emulator yang terdapat pada aplikasi developer Intel XDK sedangkan database aplikasi di letakkan di localhost komputer. Setelah pengujian berhasil, aplikasi akan di upload ke sebuah cloud Intel XDK untuk dilakukan ujicoba kembali dengan menggunakan sebuah smartphone android. Jika pengujian berhasil, aplikasi di build menjadi aplikasi mobile dan di instal pada smartphone android. Kemudian database aplikasi akan diletakkan di server independen sehingga dapat diakses secara online. Selanjutnya, system requirement yang telah dipaparkan pada bagian sebelumnya, dikembangkan menjadi sebuah rancangan sistem. Perancangan sistem ini dibuat berdasarkan kaidah Unified Modelling Language (UML). UML merupakan sebuah metode untuk merepresentasikan atau mendeskripsikan desain perangkat lunak ke dalam notas-notasi grafis yang terstandarisasi. Dengan UML, rancangan perangkat lunak dapat direpresentasikan ke dalam diagram-diagram yang memiliki fungsi masing-masing. Berikut adalah diagram-diagram yang menggambarkan rancangan dari sistem yang akan dibuat, meliputi Flowchart, activity diagram, sequence diagram, dan class diagram.

\subsubsection{Flowchart sistem}

Flowchart sistem merupakan flowchart yang menggambarkan alur sistem secara umum. Dimulai ketika aplikasi mulai dinyalakan maka muncul tampilan menu utama, kemudian memanggil data berdasarkan kategori, setelah memilih salah satu kategori, sistem akan memanggil POI berdasarkan kategori yang telah dipilh, sensor GPS, kompas dan kamera akan langsung aktif secara bersamaan pada layar perangkat akan menampilkan tampilan augmented reality yang ditandai dengan munculnya 
tampilan kamera. Sistem kemudian akan melakukan waiting sampai seluruh objek POI berhasil ditampilkan. Objek-objek tersebut kemudian akan ditampilkan sesuai nama yang telah didefinisikan pada setiap POI. User dapat memilih salah satu POI tersebut dan akan menampilkan informasi yang berupa nama dan keterangan dari POI tersebut serta direction menuju lokasi tersebut. Selain menampilkan mode augmented reality, terdapat pilihan untuk menampilkan POI dengan mode list view maupun mode map view.
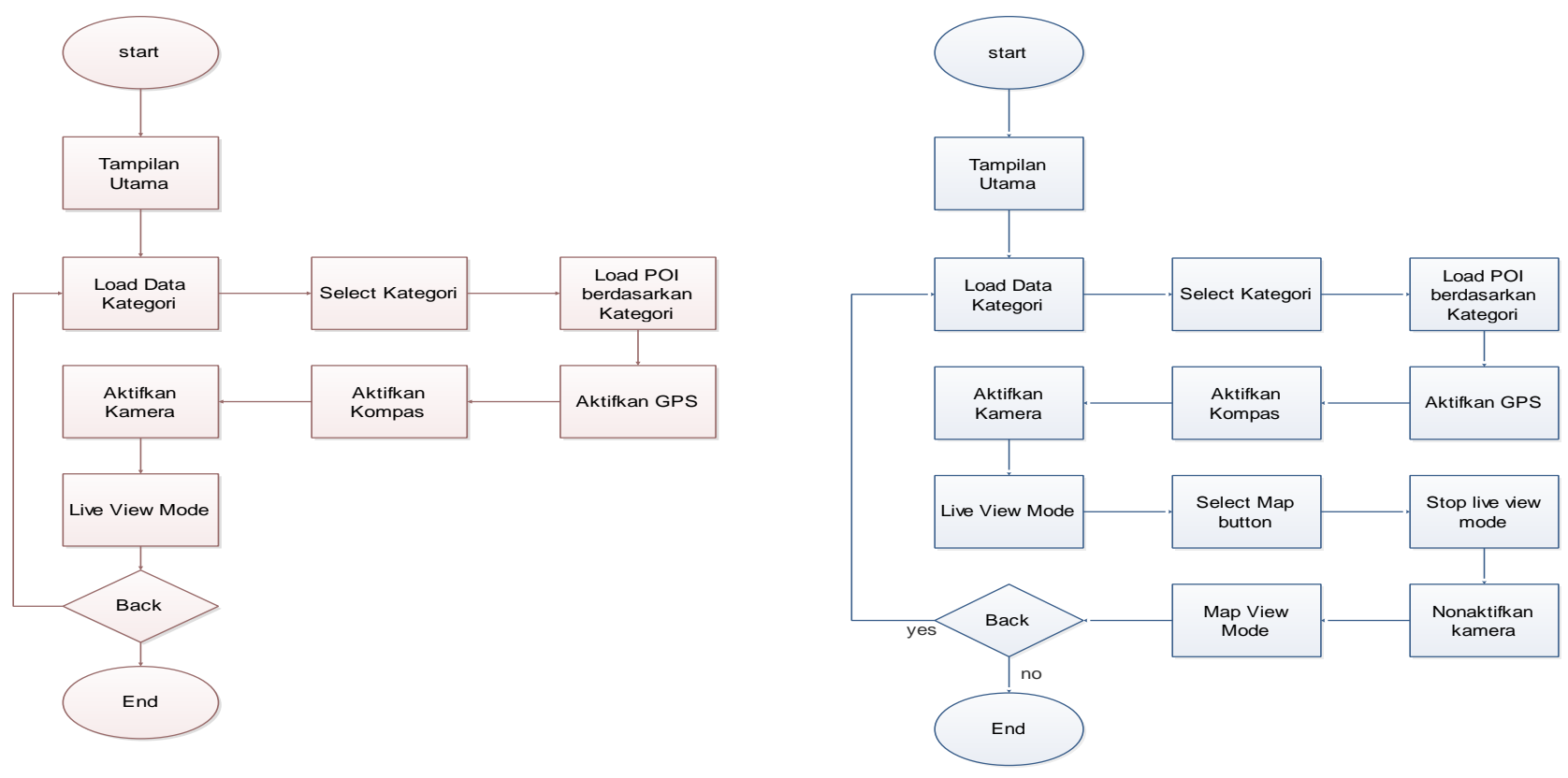

Gambar 9. Flowchart Live View

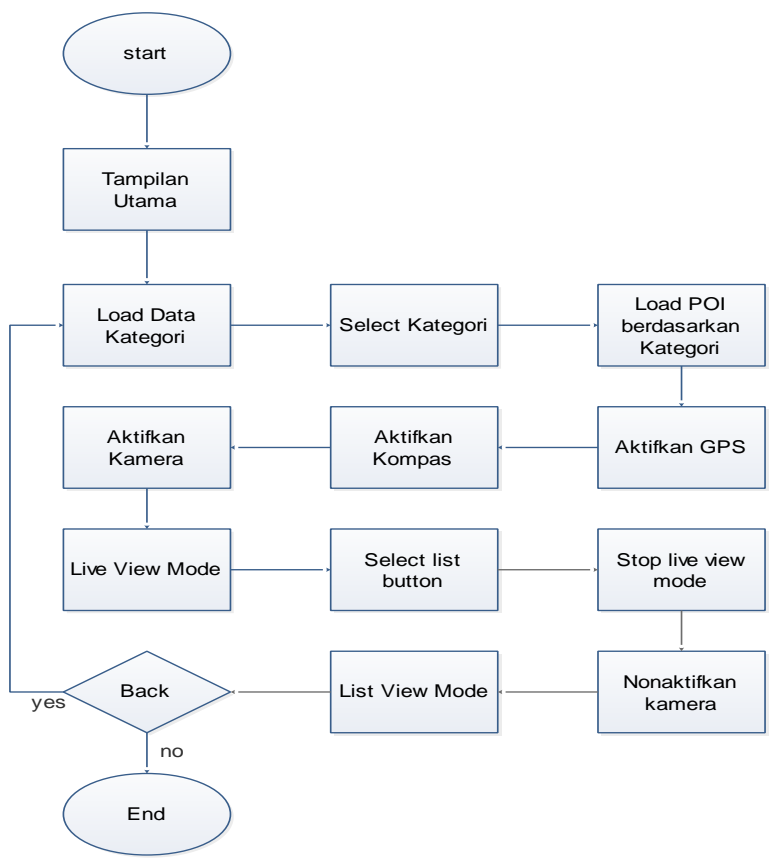

Gambar 10. Flowchart List View

\subsubsection{Class Diagram}

Dibawah ini merupakan class diagram yang menggambarkan beberapa kelas yang digunakan dalam sistem ini beserta atribut-

Gambar 11. Flowchart Map View

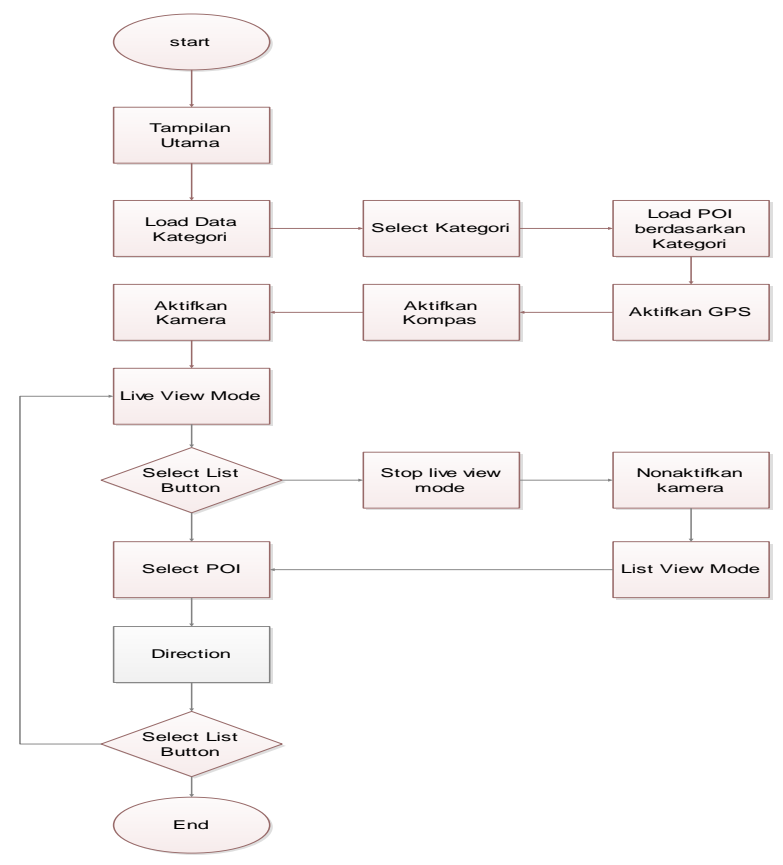

Gambar 12. Flowchart Direction

atribut proses-proses dan relasi-relasi yang terdapat didalamnya. 


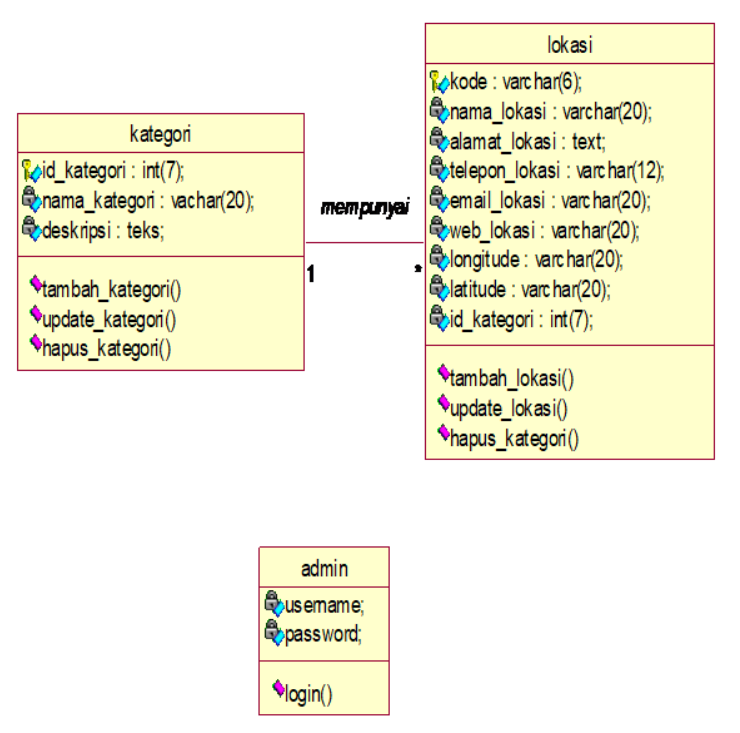

Gambar 13. Class Diagram

\subsubsection{Activity Diagram}

Kegunaan diagram ini adalah untuk memodelkan workflow atau jalur kerja, memodelkan operasi, bagaimana objek-objek bekerja, aksi-aksi dan pengaruh terhadap objek. Berikut gambar activity diagram pada masing-masing user yang menunjukkan aksi pada sistem:

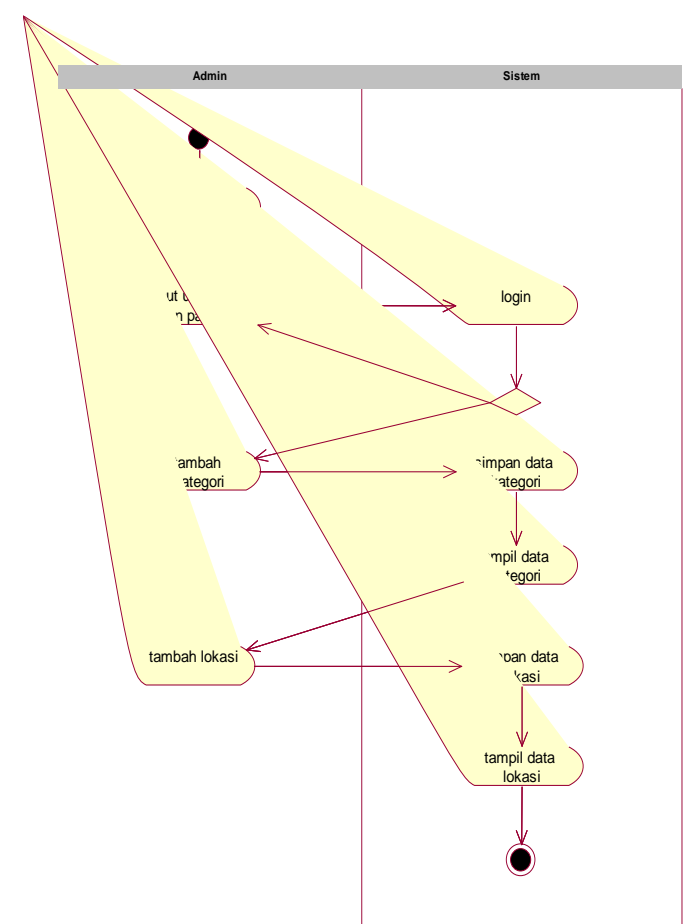

Gambar 14. Activity Diagram Administrator

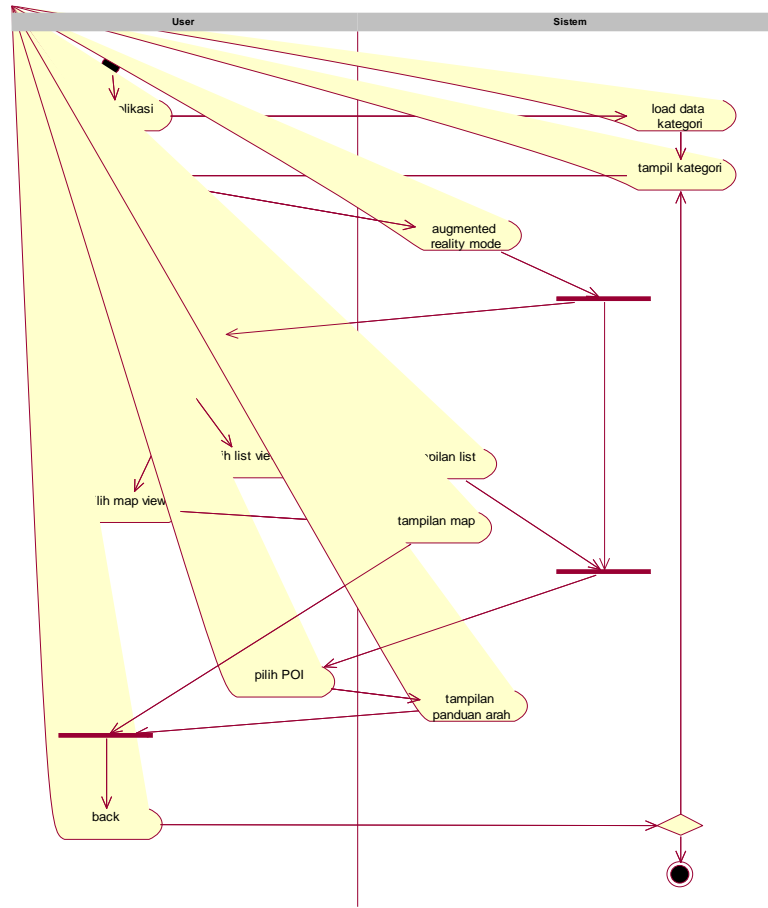

Gambar 15. Activity Diagram User

\subsubsection{Sequence Diagram}

Sequence diagram menggambarkan interaksi antar objek di dalam dan di sekitar sistem (termasuk pengguna, display, dan sebagainya), serta berupa pesan yang digambarkan terhadap waktu.

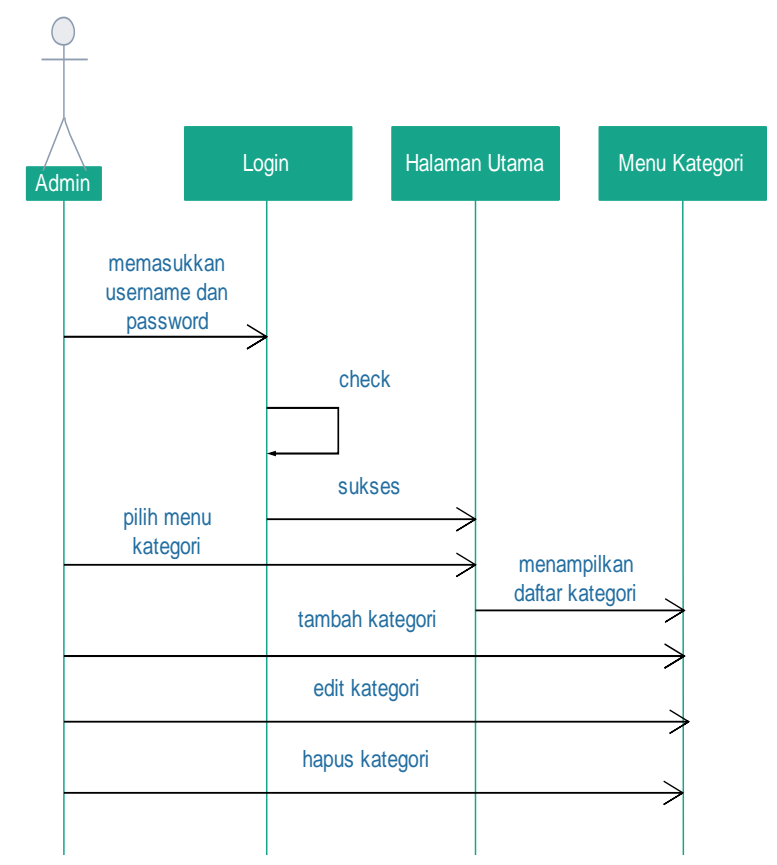

Gambar 16. Sequence Diagram Kelola Kategori 


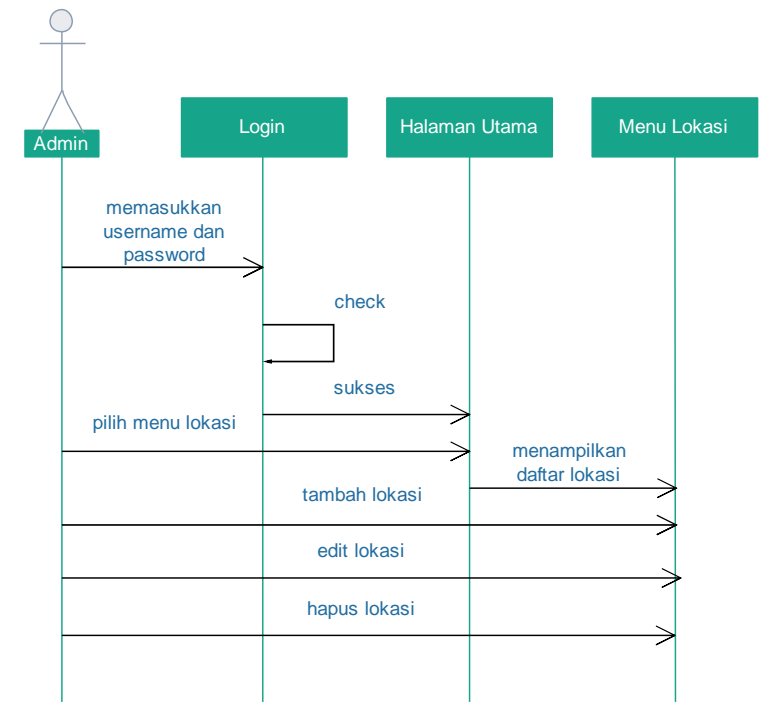

Gambar 17. Sequence Diagram Kelola Lokasi

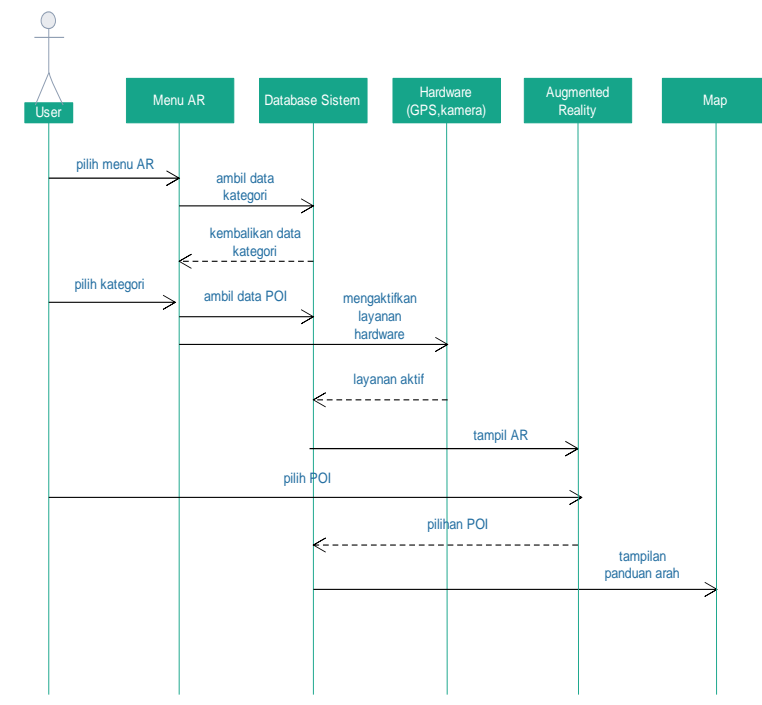

Gambar 18. Sequence Diagram User

\section{HASIL DAN PEMBAHASAN}

Database Aplikasi

Setelah melakukan perancangan dan konfigurasi, pada bagian ini penulis akan menjalankan dan mengujicoba aplikasi serta menghubungkan aplikasi dengan database MySQL yang terdapat di luar aplikasi ini. Adapun database MySQL yang telah di buat sebagai berikut.

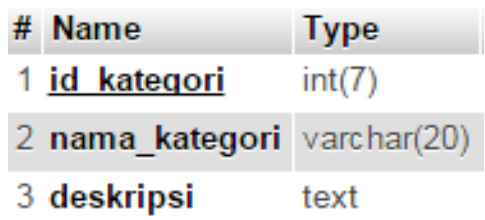

Gambar 19. Struktur Tabel Kategori

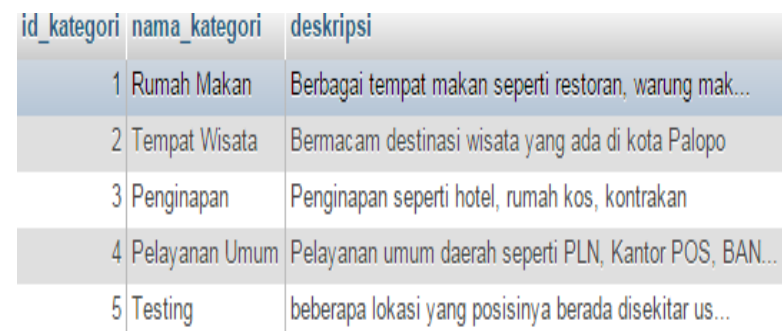

Gambar 20. Tabel Kategori

\begin{tabular}{l|l|}
\hline \# Name & Type \\
1 kode & $\operatorname{varchar}(6)$ \\
\hline 2 nama_lokasi & varchar(20) \\
\hline 3 alamat_lokasi & text \\
\hline 4 telepon_lokasi & varchar(12) \\
\hline 5 email_Iokasi & varchar(20) \\
\hline 6 web_lokasi & varchar(20) \\
\hline 7 latitude & $\operatorname{varchar}(20)$ \\
\hline 8 longitude & $\operatorname{varchar}(20)$ \\
\hline 9 id_kategori & int(11) \\
\hline
\end{tabular}

Gambar 21. Struktur Tabel Lokasi

\begin{tabular}{|c|c|c|c|c|c|c|}
\hline kode & nama_lokasi & alamat lokasi & telepon_li email_lokasi & web_loki latitude & longitude & id__ategori \\
\hline lok001 A & Ayam penyet Ria & JI. DR. Ratulangi & - & -29913987 & 120.1904175 & 5 \\
\hline lok002 F & Restoran Miramar & Jl. Andi Tadda baru & 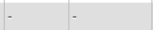 & -29959074 & 1201959364 & 1 \\
\hline 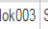 & Sido Mampir & Jl. Andi Djemma & - & -29928882 & 120.1952906 & 1 \\
\hline lok004 F & Pantai Labombo & Jl. Mungkasa & & -30014774 & 1202152297 & 2 \\
\hline |ok005 | & Istana Datu Luwu & JI. Andi Machulau & & -29942404 & 120.1946031 & 2 \\
\hline lok006 & Bukit Sampoddo & $\begin{array}{l}\text { JI. Poros-Makassar } \\
\text { (Kec. Wara Selatan) }\end{array}$ & & -3048539 & 120225983 & 2 \\
\hline lok007 & $\begin{array}{l}\text { Rumah Adat } \\
\text { Langkanaee }\end{array}$ & Jl. Yusuf Ainef (Kec. Wara) & & -29936253 & 120.1938819 & 2 \\
\hline lok008 ト & Hotel Platinum & JI. Andi Machulau & & -29971243 & 1201972003 & 3 \\
\hline lok009 r & Hotel Agro & JI. Pongsimpin & - & -3.0171838 & 120.1820834 & 3 \\
\hline lok010 |r & Hotel Citra Buana & Jl. Andi Djemma & - & 3.0120643 & 120.2052651 & 3 \\
\hline lok011 k r l l r & KPC BCA & Jl. Mangga & 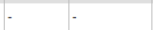 & -3.0020036 & 120.1949797 & 4 \\
\hline lok012 k r l l & Kantor Pos & Jl. Ahmad Yani no. 15 & & -29948337 & 1201951008 & 4 \\
\hline lok013C & City Market Palopo & JI. Dr. Ratulangi & - & -29906434 & 120.1869735 & 4 \\
\hline lok014 & $\begin{array}{l}\text { Rumah Sakit At- } \\
\text { Medik }\end{array}$ & JI. Jendral Sudirman & & -3.0033874 & 120.1981753 & 4 \\
\hline lok015 F r l r & Pusat Niaga Palopo & Jl. Mangga & - & -3.0007822 & 120.1955161 & 4 \\
\hline lok016 r & Hotel Awara & JI. Latamacelling & & -29938673 & 120.1961401 & 3 \\
\hline
\end{tabular}

Gambar 22. Tabel Lokasi

\begin{tabular}{|l|l|}
\hline \# Name & Type \\
\hline 1 id user & int $(7)$ \\
\hline 2 password & varchar(8) \\
\hline 3 email & varchar(20) \\
\hline 4 username & varchar(20) \\
\hline 5 alamat_user & text \\
\hline 6 nomor_user & varchar(12) \\
\hline
\end{tabular}

Gambar 23. Struktur Tabel Administrator 
Database terdiri tiga tabel, yaitu tabel kategori, tabel lokasi dan tabel administrator. Database tersebut hanya dapat diakses oleh seorang administrator yang telah terdaftar dalam tabel administrator.

Administrator menambahkan data kategori terlebih dahulu, kemudian data lokasi ditambahkan berdasarkan kategori masing-masing. Tiap lokasi / point of interest memiliki nilai longitude dan latitude yang merupakan titik koordinat pada google map, seperti pada data ayam penyet ria di gambar 4.4 tabel lokasi. Nilai latitude dan longitude diperoleh dari pengambilan data pada google map seperti pada gambar 4.6.

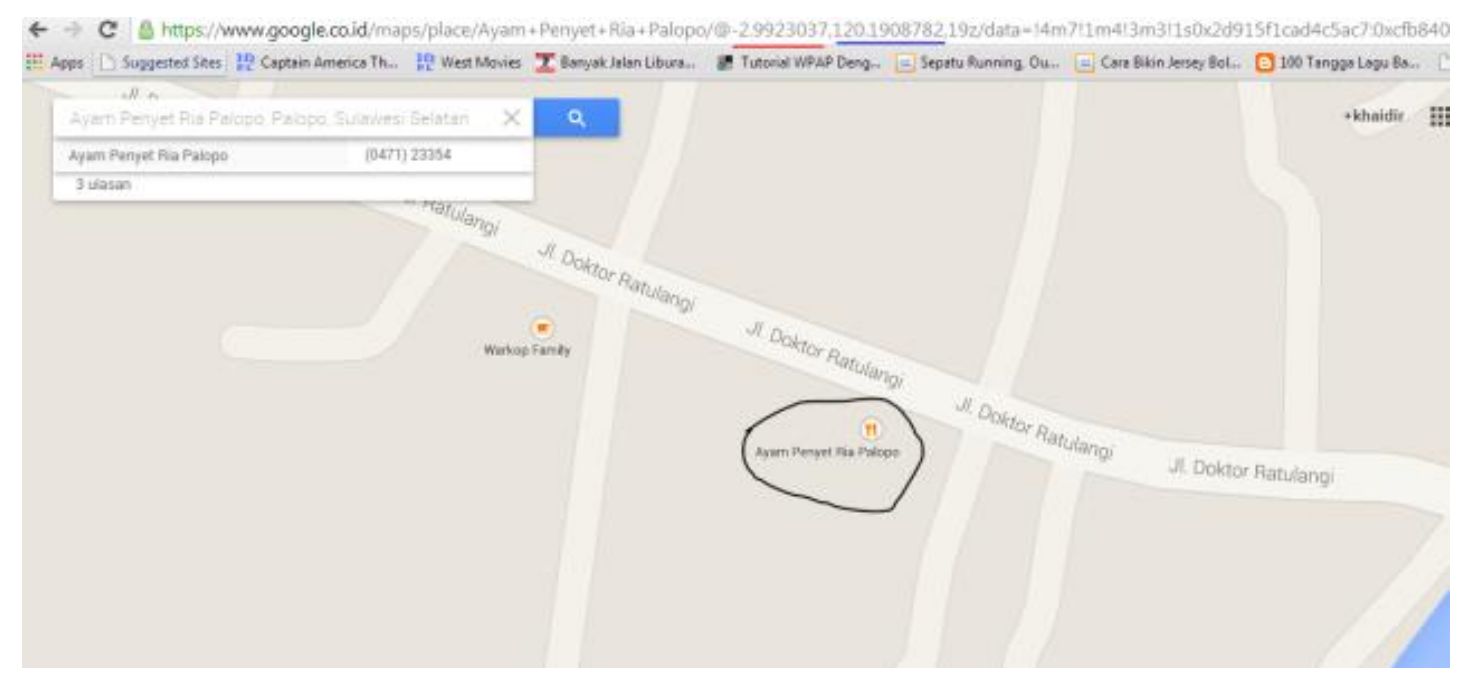

Gambar 24. Pengambilan data di Google Map

\subsection{Website Administrator}

Administrator melakukan seluruh proses penambahan data lokasi dan kategori pada sebuah website administrator. Database MySQL ini telah terkoneksi dengan website administrator yang dihosting dalam sebuah website service sehingga administrator dapat mengelola data secara online. Berikut listing code dari koneksi database MySQL dan website administrator.

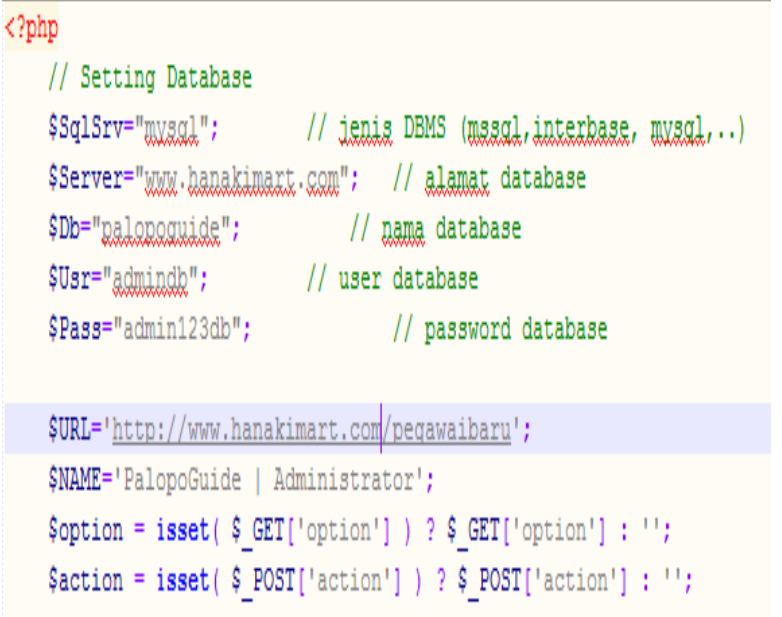

Gambar 25. koneksi database MySQL

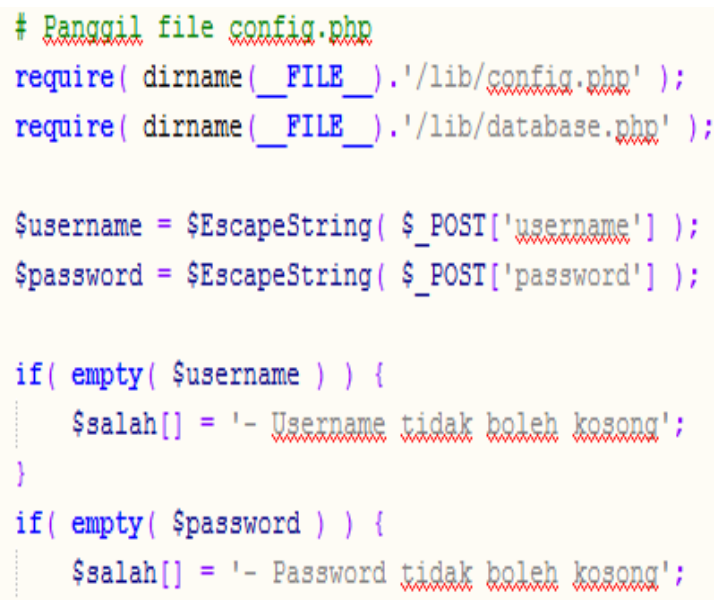

Gambar 26. fungsi config.php

Database MySQL telah tersimpan dalam website server hanakimart.com kemudian terdapat sebuah file php dengan nama config.php seperti pada gambar 4.8 yang berfungsi menghubungkan database MySQL dengan website administrator. Tampilan website administrator sebagai berikut. 


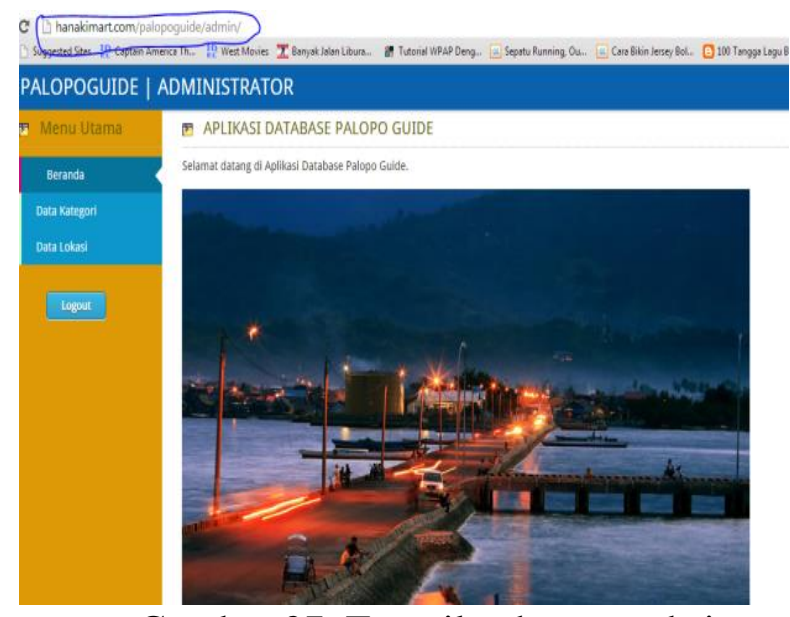

Gambar 27. Tampilan home website administrator

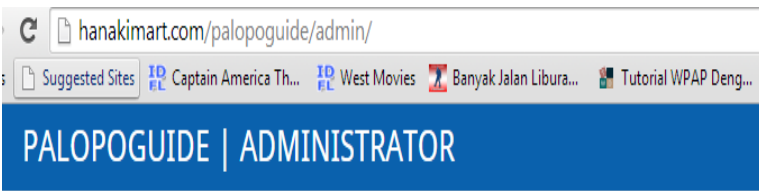

国 ::LOGIN::

\section{Username: \\ 8. Isi username. \\ Password:}

8. Isi password...

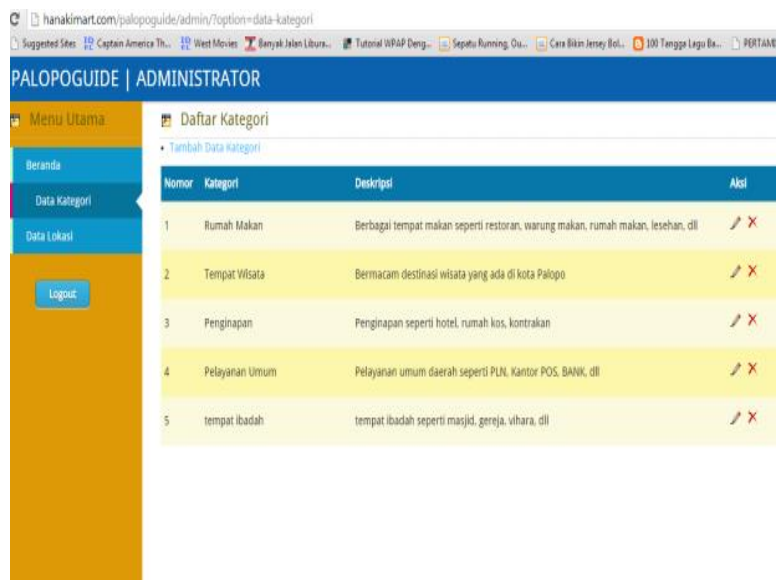

Gambar 29. Menu Kategori

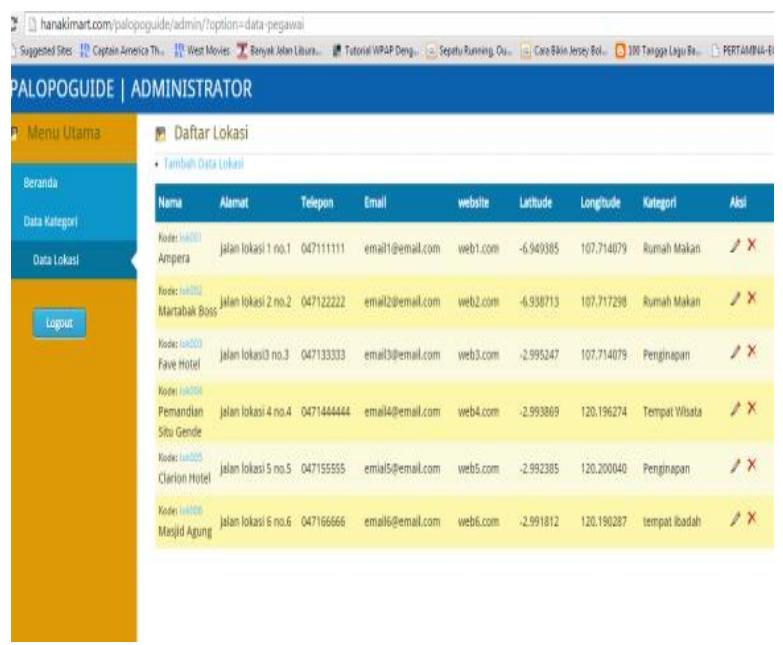

Gambar 30. Menu Lokasi

Gambar 28. Login website administrator

Administrator melakukan login dengan cara memasukkan username dan password seperti pada gambar 4.10. setelah berhasil login, administrator diarahkan ke tampilan home website administrator pada gambar 4.9 terdapat beberapa menu pengelolaan data, yaitu menu beranda, menu data kategori dan menu data lokasi seperti pada gambar 4.11 dan gambar 4.12. Administrator dapat menambahkan, menghapus, maupun mengubah data kategori dan data lokasi seperti pada gambar berikut.

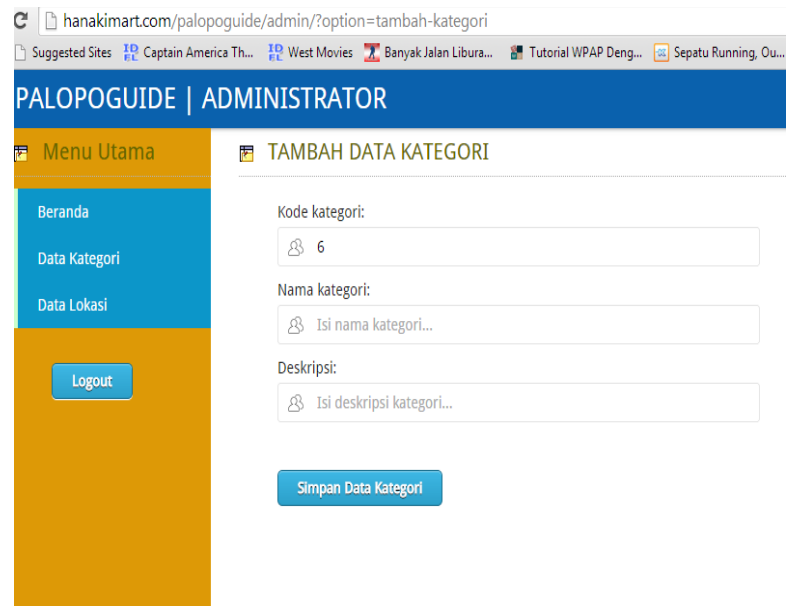

Gambar 31. Tambah Data Kategori

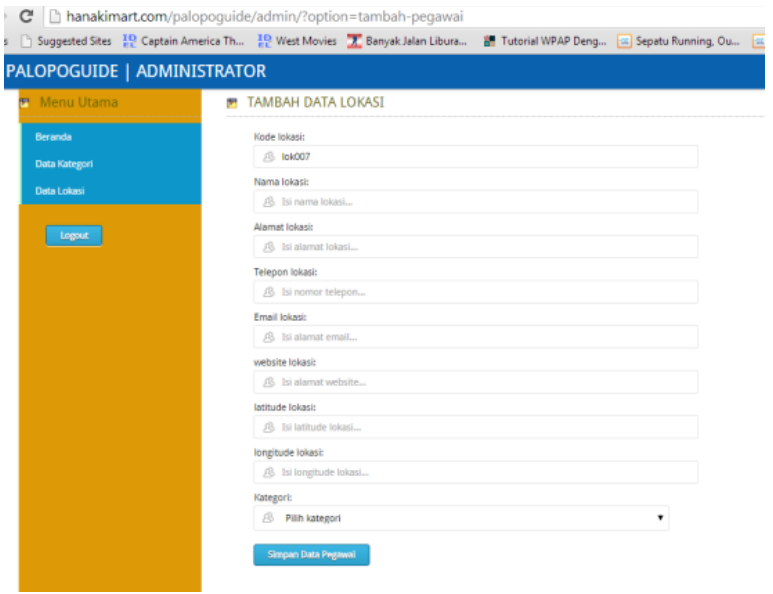

Gambar 32. Tambah Data Lokasi 


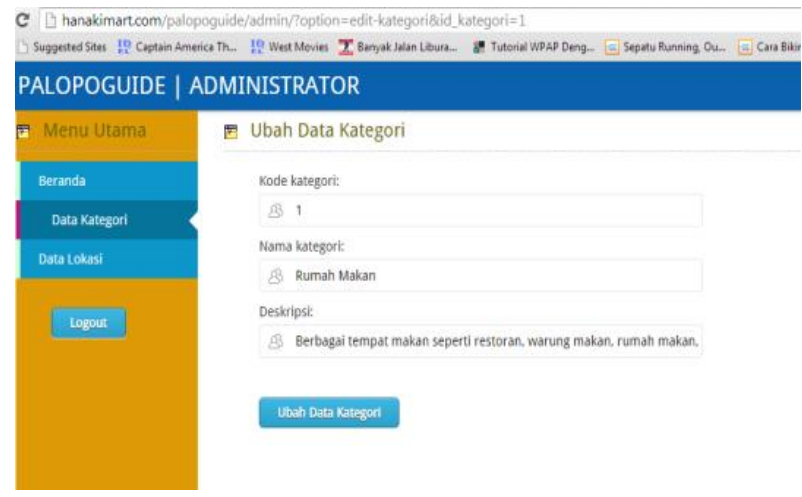

Gambar 33. Edit Data Kategori

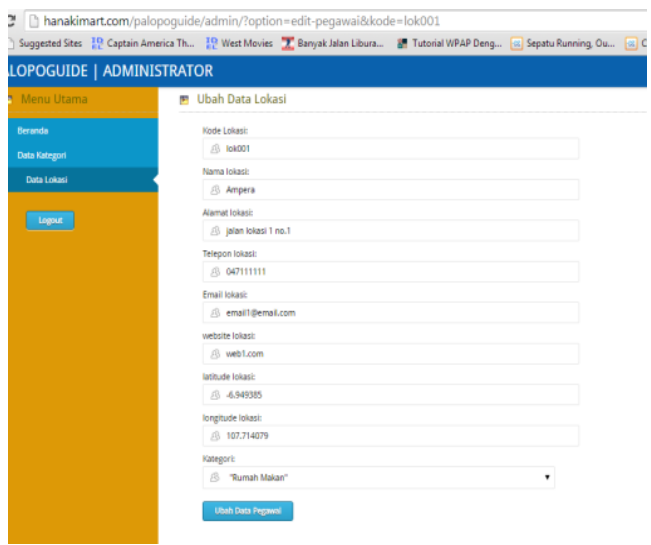

Gambar 34. Edit Data Lokasi

\subsection{Aplikasi Mobile}

Projek aplikasi dibuat dengan menggunakan aplikasi developer kit Intel XDK. Melalui aplikasi ini developer dapat mengelola projek aplikasi, melakukan simulasi serta melakukan build aplikasi menjadi aplikasi mobil.

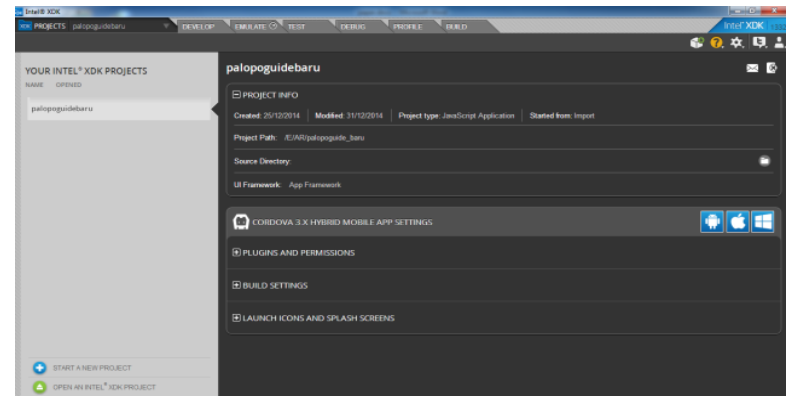

Gambar 35. Tampilan Awal Intel XDK

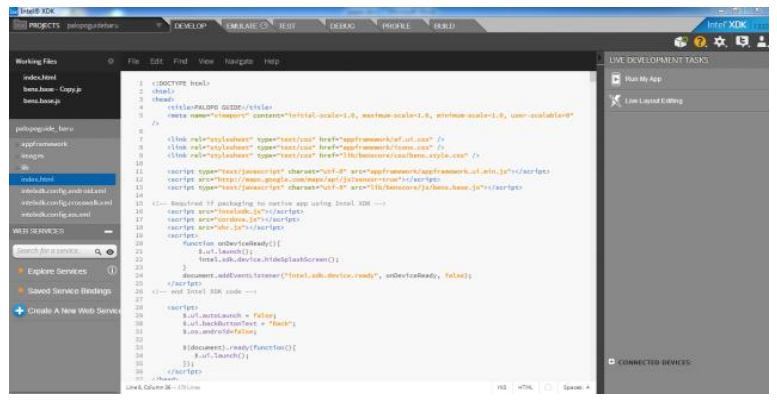

Gambar 36. Kelola Projek

Gambar 4.16 memperlihatkan tampilan awal aplikasi intel xdk. Terdapat beberapa pilihan untuk memulai projek dengan cara memulai projek baru, membuka projek yang telah ada maupun menggunakan template yang disediakan. Dalam pengembangan aplikasi panduan kota palopo, proses pembuatannya menggunakan bahasa pemrograman HTML5 dengan menggunakan framework mobile. File html tersebut dikelola pada aplikasi intel xdk seperti pada gambar 4.17

Intel XDK menyediakan fitur Emulator yang memudahkan developer dalam melakukan running project, fitur emulate terdapat pada menu bar aplikasi. Tampilan emulate menyerupai tampilan mobile, terdapat berbagai macam model device smartphone yang dapat digunakan dalam simulasi ini. Pada pengembangan aplikasi panduan kota palopo, simulasi projek menggunakan model smartphone Google nexus 4 seperti pada gambar 4.18.

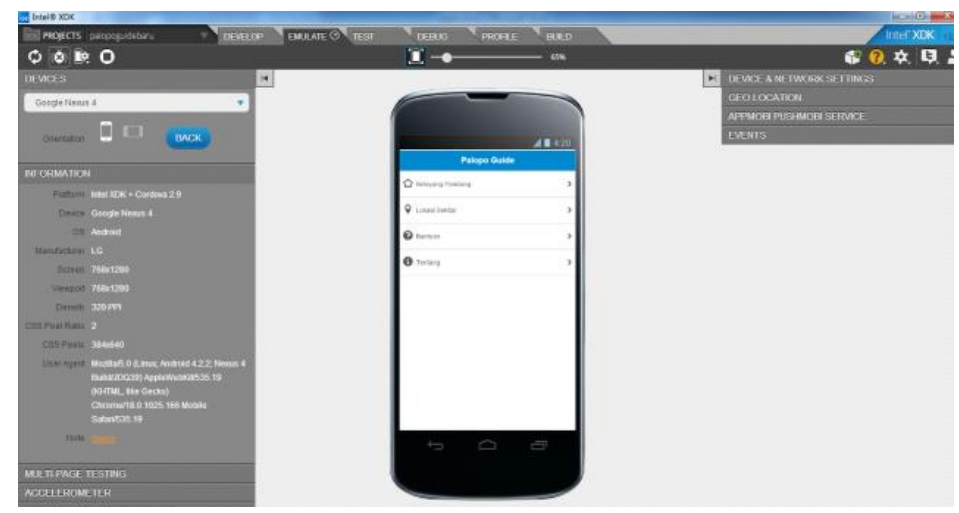

Gambar 37. Emulate Projek 
Fitur emulator ini dapat menjalankan projek aplikasi, namun beberapa fungsi hardware smartphone tidak dapat bekerja pada emulator, sehingga untuk menguji secara langsung pada smartphone diperlukan aplikasi intel xdk vesi mobile serta data projek yang telah di upload pada server intel xdk sehingga projek dapat diujicoba langsung di smartphone.

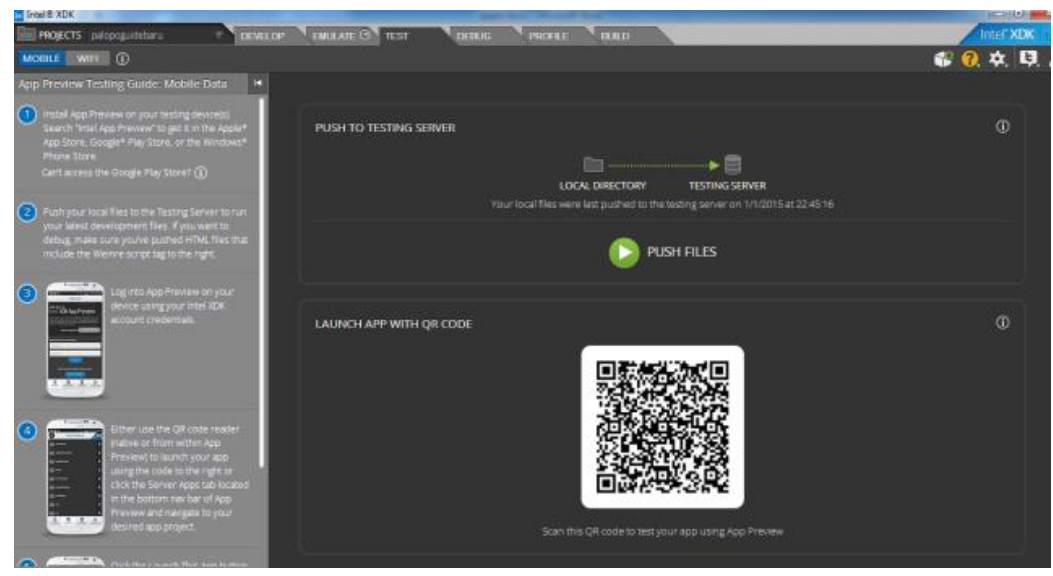

Gambar 38. Push File Projek

Data projek di upload ke server Intel xdk menggunakan fitur test pada menu bar aplikasi. Proses push file membutuhkan waktu sekitar satu menit, durasi tergantung pada besar projek.

Setelah melakukan testing projek, data siap untuk di build kedalam aplikasi mobile. Seperti pada gambar 4.20 terdapat beberapa pilihan build aplikasi, yaitu android, ios dan windows 8 .

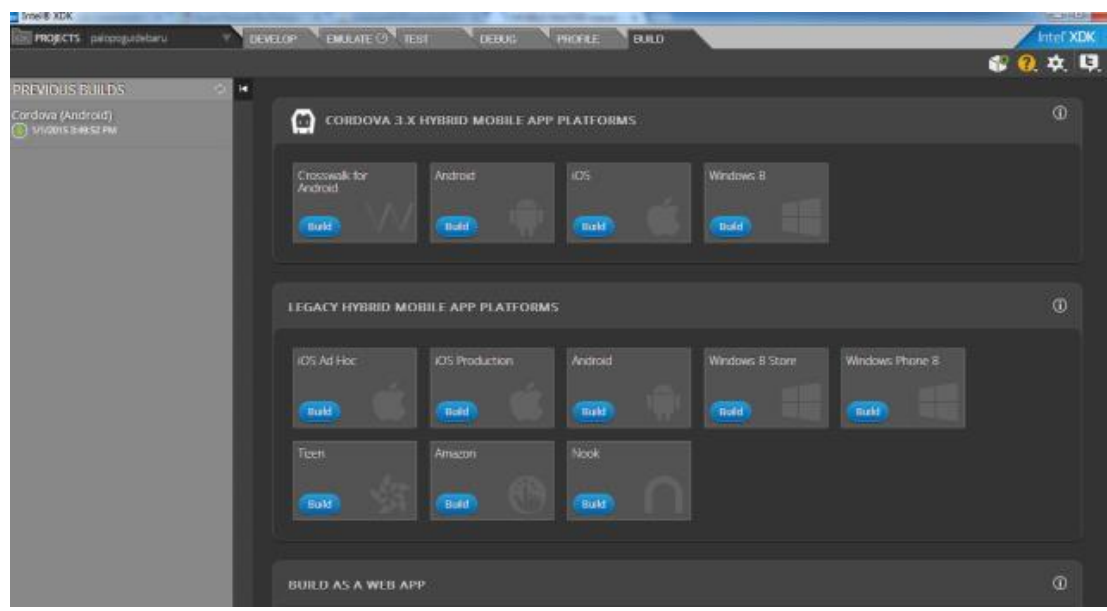

Gambar 39. Build Aplikasi

\subsection{Pengujian Aplikasi}

Pengujian aplikasi secara mobile menggunakan smartphone android dengan spesifikasi sebagai berikut.

1. Nama device: Motorola G

2. RAM : $1 \mathrm{gb}$

3. ROM : $8 \mathrm{gb}$

4. OS : Android OS, v4.3 (Jelly Bean)

5. Kamera : $5 \mathrm{MP}$

6. CPU : Quad-core $1.2 \mathrm{GHz}$ Cortex-A7

Setelah menjalankan aplikasi panduan kota palopo, akan muncul menu utama aplikasi (gambar 4.21). Namun untuk menggunakan aplikasi ini user perlu mengaktifkan GPS dan akses data internet. 


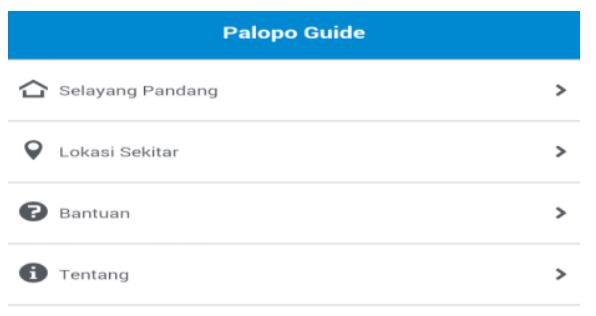

\section{$\longleftrightarrow \quad \square$}

Gambar 40. Tampilan Awal Aplikasi

Selanjutnya terdapat empat menu pilihan di tampilan awal aplikasi yaitu :

1. Menu "Selayang Pandang" untuk menampilkan informasi kota Palopo.

2. Menu "Lokasi Sekitar" untuk menampilkan menu kategori yang berisi lokasi-lokasi yang ditampilkan dalam mode augmented reality, list maupun map.

3. Menu "Bantuan" untuk menampilkan cara penggunaan aplikasi.

4. Menu "Tentang" untuk menampilkan data diri pengembang aplikasi.

Ketika menu "Selayang Pandang" dipilih, selanjutnya muncul informasi singkat tentang kota Palopo (gambar 4.22).

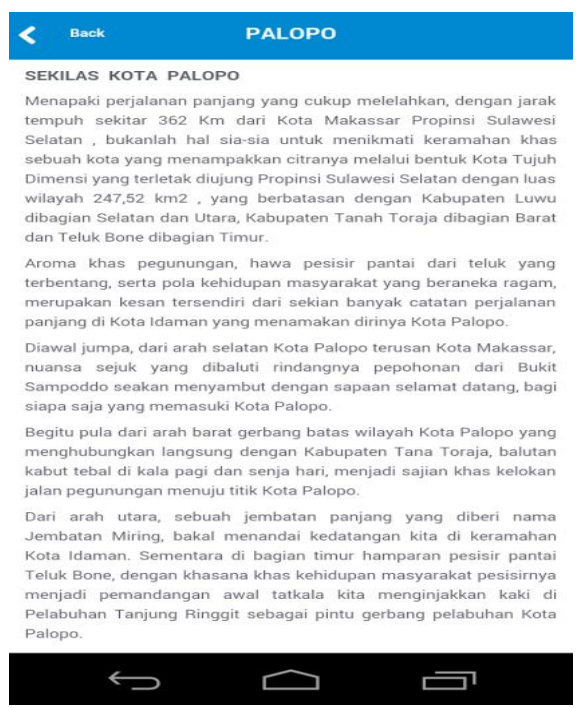

Gambar 41. Menu Selayang Pandang

Ketika menu "Lokasi Sekitar" dipilih, selanjutnya muncul tampilan daftar menu kategori (gambar 4.23). daftar menu kategori diambil berdasarkan data pada database MySQL. Ketika user memilih salah satu kategori, maka aplikasi akan muncul tampilan augmented reality beserta POI sesuai dengan daftar lokasi yang ada di database MySQL (gambar 4.24).
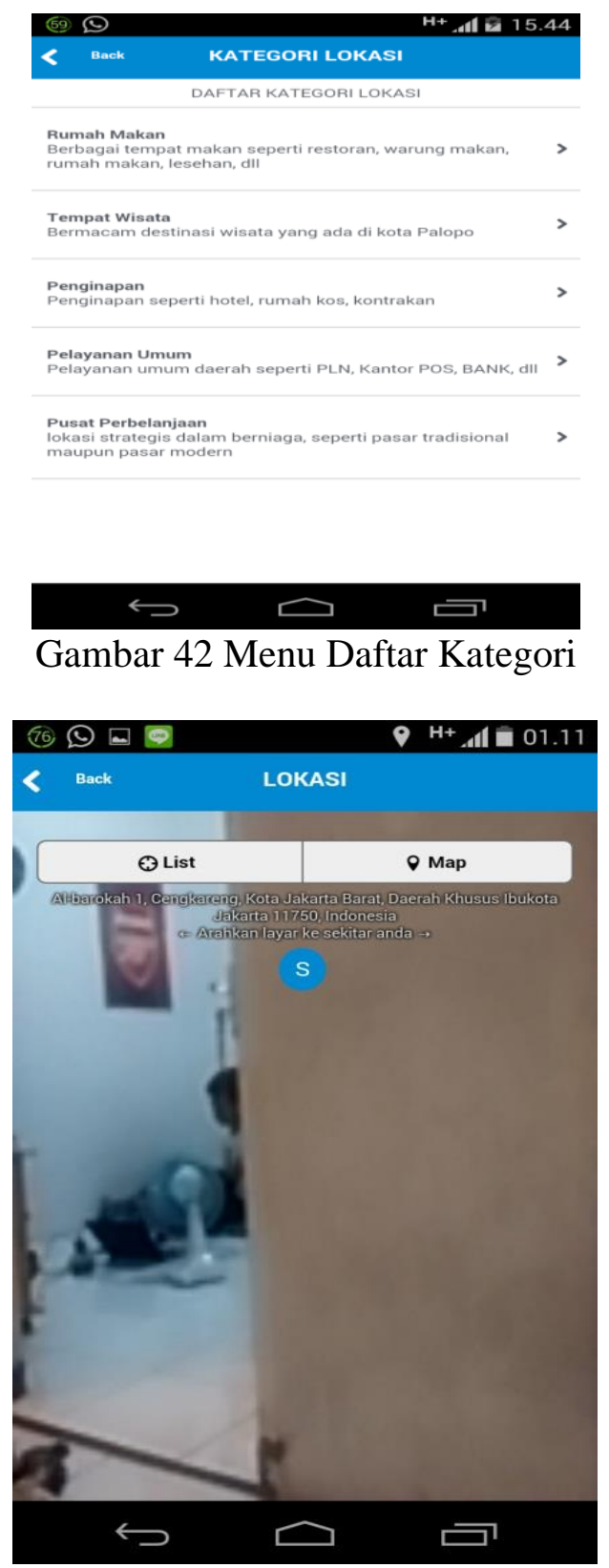

Gambar 43. Tampilan Augmented Reality

Jika kamera diarahkan dengan koordinat yang sama dengan nilai latitude dan nilai longitude dari data yang telah di input di database, maka POI akan muncul di layar augmented reality (gambar 4.25). Pada gambar 4.26, ukuran POI terlihat besar, dikarenakan 
ukuran POI pada tampilan augmented reality tergantung pada jarak POI terhadap posisi user. Semakin jauh posisi POI terhadap user, maka ukuran POI akan terlihat semakin kecil. Jika salah satu POI dipilih, maka menampilkan panduan arah menuju lokasi POI, panduan arah berisi map serta daftar direction yang diambil dari google map (gambar 4.27).

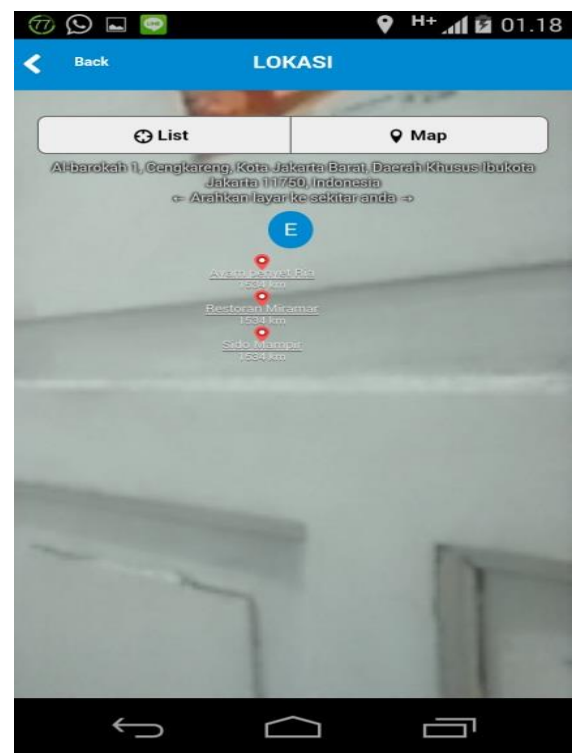

Gambar 44. Tampilan AR dengan POI

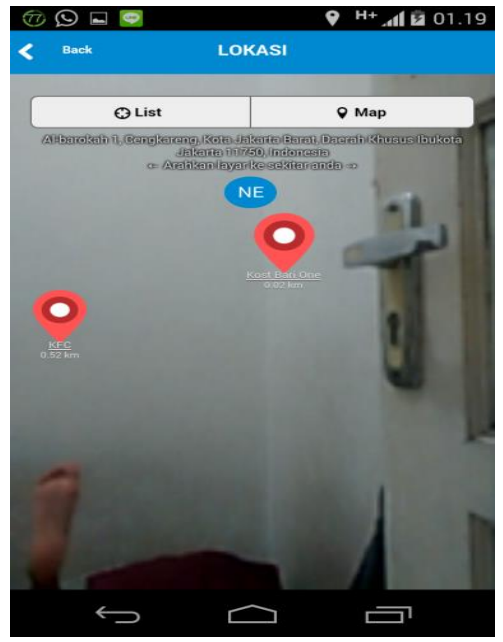

Gambar 46. Posisi POI yang dekat

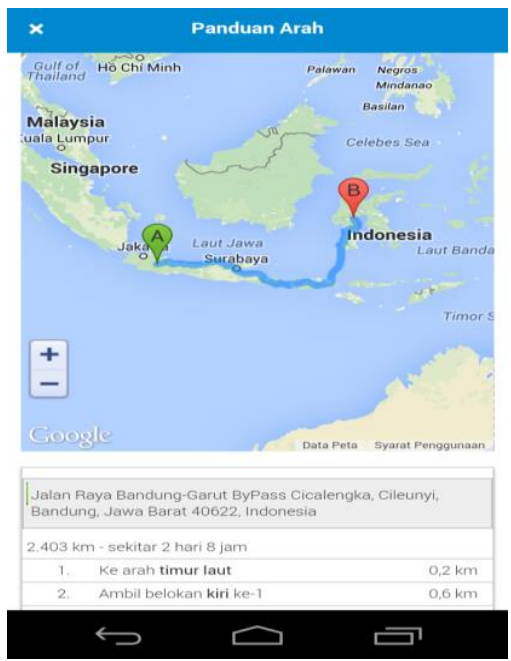

Gambar 47. Panduan arah POI

Aplikasi panduan kota palopo tidak hanya menampilan data lokasi dengan teknologi augmented reality, namun dapat ditampilkan dalam bentuk list maupun map. Pada tampilan augmented reality terdapat dua button yaitu list button dan map button. Jika list button dipilih, maka daftar lokasi (POI) akan ditampilkan dalam bentuk list (gambar 4.28) sedangkan map button akan menampilkan data lokasi berdasarkan posisi lokasi pada map (gambar 4.29). Pada tampilan list, jika salah satu data lokasi dipilh, akan menampilkan panduan arah seperti pada gambar 4.27

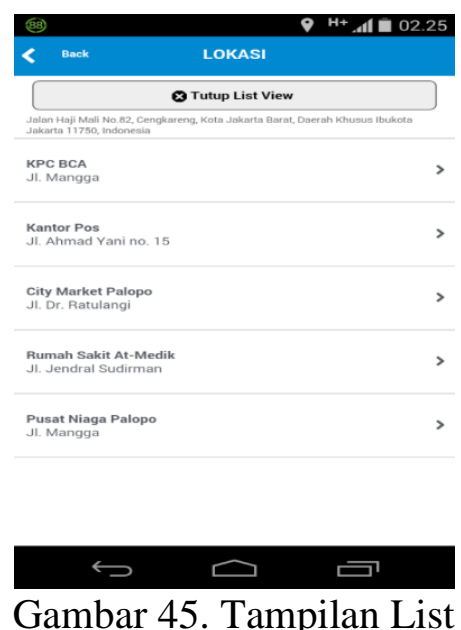

Gambar 45. Tampilan List

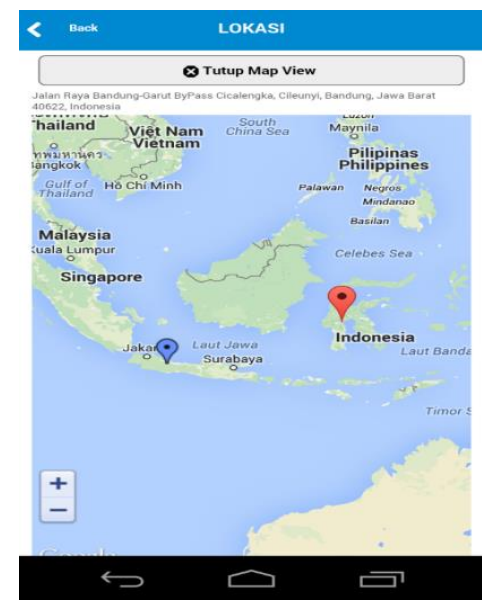

Gambar 48. Tampilan Map 


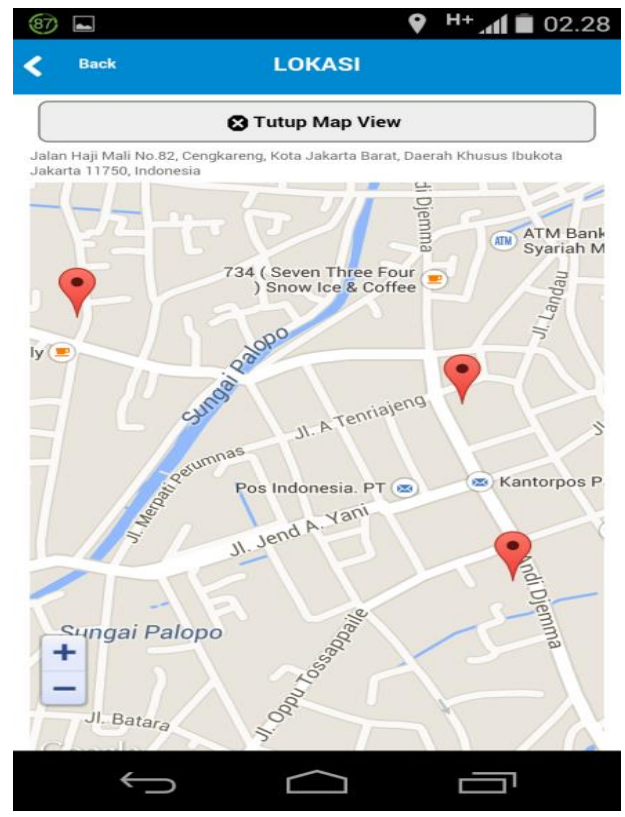

Gambar 49. Perbesaran Tampilan Map

Pada menu "Bantuan", akan menampilkan petunjuk penggunaan aplikasi (gambar 4.31) sedangkan pada menu "tentang" menampilkan data diri pengembang aplikasi (gambar 4.32).

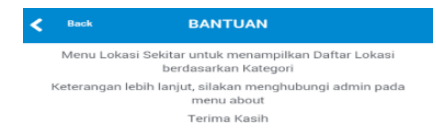

Gambar 50. Menu Bantuan

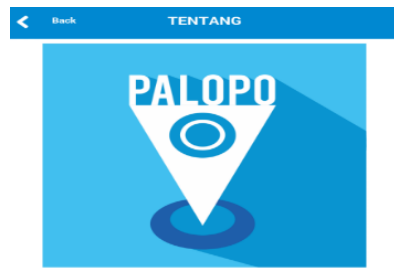

Khaidir Mubarak Putrasyam 2011-31-019
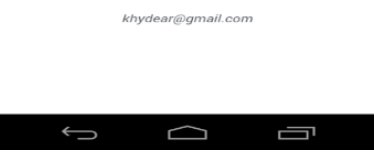

Gambar 51. Menu Tentang

\section{KESIMPULAN}

Berdasarkan implementasi dan uji coba aplikasi yang dibangun, penulis dapat menarik beberapa kesimpulan, yaitu:

a. Aplikasi hanya dapat dijalankan jika tersedia akses paket data dari provider yang digunakan oleh user.

b. Durasi waktu yang dibutuhkan untuk mengakses data aplikasi tergantung pada sinyal data internet dari provider yang digunakan oleh user.

c. Keakuratan posisi user yang diterima GPS di handset bisa meleset beberapa meter dari posisi yang sebenarnya, dikarenakan penentuan posisi tergantung oleh hardware GPS di handset user.

d. Pengambilan data lokasi dan kategori sepenuhnya tergantung pada ketersediaan server, jadi jika server tidak hidup dikarenakan pemadaman listrik ataupun gangguan teknis maka aplikasi tidak dapat menampilkan data kategori dan data lokasi (POI) yang ada di database server.

e. POI (Point of Interest) di tampilan berdasarkan kategori yang telah di pilih oleh user pada menu kategori.

\section{DAFTAR PUSTAKA}

Chairunnisa, Grafiaramagda. (18 Januari 2013). Analisa Implementasi Aplikasi Augmented Reality untuk Informasi Lokasi Lingkungan FTUI pada Android menggunakan Wikitude [online]. Tersedia: http://lib.ui.ac.id/opac/ui/detail.jsp?id=20331895\&lokasi=lokal diakses pada 19 November 2014

Rompas, B.R. Aplikasi Location-Based Service Pencarian Tempat Di Kota Manado Berbasis Android [online]. Tersedia: ejournal.unsrat.ac.id/index.php/elekdankom/article/view/600 diakses pada 14 November 2014

Budiyatno, Slamet. (2 Juli 2012). Implementasi Sistem Pengenalan Wajah Sebagai Penghubung Jejaring Sosial : Penerapan Augmented Reality sebagai Penampil Informasi Hasil 
Pengenalan Wajah pada Perangkat Android [online]. Tersedia lib.ui.ac.id/file? file=digital/20306403-S42173-Slamet\%20Budiyatno.pdf diakses pada 30 November 2014

Yusuf, Muhammad. (2013). Pelatihan Intel XDK Modul 1. Pengenalan HTML5, Mobile Application dan Intel XDK [online]. Tersedia: http://www.slideshare.net/ruangchupa/modul-1pengenalan-html5-mobile-application-dan-intel-xdk?related $=1$ diakses pada 20 November 2014 